\title{
The relationship between transformational leadership and leadership effectiveness in Kenyan indigenous banks
}

\begin{tabular}{|c|c|}
\hline \multicolumn{2}{|c|}{$\begin{array}{l}\text { Authors: } \\
\text { Lynette Louw }{ }^{1} \text { (1) } \\
\text { Samuel M. Muriithi }{ }^{1} \text { (1) } \\
\text { Sarah Radloff }{ }^{2}\end{array}$} \\
\hline \multicolumn{2}{|c|}{$\begin{array}{l}\text { Affiliations: } \\
{ }^{1} \text { Department of } \\
\text { Management, Rhodes } \\
\text { University, South Africa }\end{array}$} \\
\hline \multicolumn{2}{|c|}{$\begin{array}{l}{ }^{2} \text { Department of Statistics, } \\
\text { Rhodes University, } \\
\text { South Africa }\end{array}$} \\
\hline \multicolumn{2}{|c|}{$\begin{array}{l}\text { Corresponding author: } \\
\text { Lynette Louw, } \\
\text { l.louw@ru.ac.za }\end{array}$} \\
\hline \multicolumn{2}{|c|}{$\begin{array}{l}\text { Dates: } \\
\text { Received: } 17 \text { Mar. } 2017 \\
\text { Accepted: } 22 \text { Aug. } 2017 \\
\text { Published: } 21 \text { Nov. } 2017\end{array}$} \\
\hline \multicolumn{2}{|c|}{$\begin{array}{l}\text { How to cite this article: } \\
\text { Louw, L., Muriithi, S.M., \& } \\
\text { Radloff, S. (2017). The } \\
\text { relationship between } \\
\text { transformational leadership } \\
\text { and leadership effectiveness } \\
\text { in Kenyan indigenous banks. } \\
\text { SA Journal of Human Resource } \\
\text { Management/SA Tydskrif vir } \\
\text { Menslikehulpbronbestuur, } \\
\text { 15(0), a935. https://doi. } \\
\text { org/10.4102/sajhrm. } \\
\text { v15i0.935 }\end{array}$} \\
\hline \multicolumn{2}{|c|}{$\begin{array}{l}\text { Copyright: } \\
\text { (C) 2017. The Authors. } \\
\text { Licensee: AOSIS. This } \\
\text { is licensed under the } \\
\text { Creative Commons } \\
\text { Attribution License. }\end{array}$} \\
\hline \multicolumn{2}{|l|}{ Read online: } \\
\hline 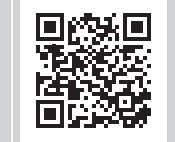 & $\begin{array}{l}\text { Scan this QR } \\
\text { code with your } \\
\text { smart phone or } \\
\text { mobile device } \\
\text { to read online. }\end{array}$ \\
\hline
\end{tabular}

Orientation: Effective leadership is critical to the survival and growth of organisations. For such leadership to be realised, organisational leaders need to be competent in transformational leadership, which is described as a situation in which the leader and followers empower and shape each other's behaviour to attain a desired goal.

Research purpose: The purpose of this study is to empirically test the relationship between transformational leadership competency and leadership effectiveness in Kenyan indigenous banks.

Motivation for this study: In spite of the fact that indigenous banks have been performing better recently, their overall poor performance is cause for concern. This study was motivated by a desire to establish the extent to which the recent improvement is attributable to transformational leadership competency and effectiveness. It is also anticipated that this investigation can highlight aspects of leadership which require more attention in order to sustain improved performance.

Research design, approach and method: The study utilised a survey method to collect both quantitative and qualitative data while probability and non-probability techniques were used to sample target population. With 494 respondents targeted in the study, 257 responses were received and analysed. Data analysis was performed using structural equation modelling with Cronbach's alpha, confirmatory factor analysis and goodness-of-fit indices for analysis and for testing relationships.

Main findings: The overall findings confirm that a strong relationship exists between transformational leadership competencies and leadership effectiveness among the leaders of the indigenous banks in Kenya.

Practical/managerial implication: Based on the findings of this study, Kenyan indigenous banks are able to identify specific and essential transformational leadership competencies and leadership effectiveness attributes.

Contribution: The study has identified that transformational leadership abilities of inspirational motivation, intellectual stimulation, individualised consideration and idealised influence, together with the leadership effectiveness indicators of cross-cultural competency, influence, follow commitment, versatility and group organisation are essential for the effectiveness of Kenyan banks.

\section{Introduction}

The banking industry is a leading agency of commerce in industrial development (Nagar, Masih \& Badugu, 2011). However, various banking practices and behaviours have been associated with major financial crises worldwide (Brunnermerier, 2009). The last six decades in particular have seen a number of international financial crises blamed on banking industry conduct, leading to poor performance by most world economies (Grant Thornton, 2013).

Banking sectors in Africa have seen slow growth, with many communities yet to profit from the numerous financial benefits that can arise from banking practices. It is notable that the banking industry in Africa is highly concentrated in the cities, with marginal distribution in the rural areas. The industry is also characterised by small markets, weak creditors, low income, low deposit levels, low intermediaries, lack of entry barriers, foreign bank dominancy and poor legal frameworks (Mlachila, Park \& Yaraba, 2013). These characteristics have resulted in Africa being the lowest financial performer compared with the rest of the world. 
Like many African countries characterised by poor performance, Kenya has undergone several decades of financial crisis, especially between 1970 and 2005. During this period, more than 20 banks and other financial institutions went bankrupt or were put under receivership (Mwangi, 2012; Sokpor, 2006). The banks that failed were all locally and privately owned (also known as indigenous banks). It has been asserted that these bank failures were attributable to factors such as ineffective leadership (Mwangi, 2012; Njuguna, 2013), which is largely associated with the type of leadership exercised and the competencies of leaders. Kenyan bank failures have also been associated with deregulation, nonperforming loans, lack of internal control mechanisms and liquidity problems, all of which relate to leadership incompetency (Ambutsi, 2005; Waweru \& Kalani, 2009). Leadership competency denotes the knowledge, skills, expertise, beliefs, value motives and personal behaviour characteristics that distinguish a leader (Pagon, Banutai \& Bizjak, 2008). According to Al-Zoubi (2012), it is the leaders' competencies which enable them to integrate and perform set tasks while at the same time ensuring that effectiveness is attained. Burns (1978) describes transformational leadership as a situation whereby leaders and followers empower each other, resulting in higher levels of morality, motivation and leadership effectiveness. Scholars such as Tang, Yin and Nelson (2010) stress that transformational leadership competency forms the basis of leadership effectiveness. Such leadership effectiveness denotes the leader's ability to exercise personal influence, skills, knowledge and abilities to accomplish expected goals or objectives (Cooper, Fenimore \& Nirenberg, 2012). Johnson, Lenartowicz and Apud (2006) state that there is a lack of adequate research on the main determinants of leadership effectiveness. This lack of research provides a further rationale for this study which also aimed to better understand the leadership effectiveness attributes that would contribute towards the improvement of the Kenyan indigenous banks' performance.

\section{Problem definition}

As in other parts of the world, the negative performance of the banking sector in Kenya for several decades has largely been attributed to ineffective leadership (Mwangi, 2012). To be effective, leaders in banking require appropriate leadership competencies in strategic thinking, technical ability and interpersonal skills; should have integrity and honesty, and team-building abilities and emotional intelligence (Amos, 2012; Barnes, 2013; Hogan \& Warrenfeltz, 2003; PricewaterhouseCoopers, 2011). However, it is transformational leadership that is considered critical to leadership effectiveness. A study by Northouse (2013) analysing 39 studies in transformational literature found that transformational leaders were more effective and produced better results in their organisations. This sentiment is supported by Weese (1994, p. 188) who emphasises that transformational leaders have a positive impact on employee satisfaction, productivity and organisational effectiveness'. Before 2005, the Kenyan indigenous banks were said to lack the appropriate competencies to steer their banks to great heights (Sokpor, 2006). This drawback was demonstrated in the poor performance of Kenyan indigenous banks, leading to vast financial losses by their stakeholders and customers. Despite the past performance of these banks, in recent years, the indigenous banks have performed better with many of them recording encouraging results (Mwangi, 2012). However, considering their poor performance in the past, this study was motivated by a desire to establish the extent to which the recent improvement is attributable to transformational leadership competency and effectiveness. It is also anticipated that this investigation can highlight aspects of leadership which require more attention in order to sustain improved performance.

In the Kenyan context, although many studies exist on the banking industry, there is no specific study focusing on leadership in the banks, especially transformational leadership (Hedley, White, Roche \& Banerjea, 2006; PWC, 2007). Bearing in mind the importance of transformational leadership in the quest to attain bank leadership effectiveness, it became critical to conducta study on the relationship between transformational leadership and leadership effectiveness among Kenyan indigenous banks, a sector considered instrumental to the country's economic development.

\section{Research objectives}

This study investigates the relationship between transformational leadership competency (independent variable) and leadership effectiveness (dependent variable) in the current Kenyan indigenous banking industry. As such, the relevant research question is whether the transformational leadership competencies of the leadership in the Kenyan indigenous banks are positively correlated to their leadership effectiveness and could be associated with the current positive performance of the sector. Two further objectives for this study are:

- To determine whether there is a positive correlation between transformational leadership competency and its sub-variables, namely, inspirational motivation, intellectual stimulation, individualised consideration, idealised influence (attributes) and idealised influence (behaviour).

- To determine whether there is a positive correlation between leadership effectiveness and its sub-variables, namely, cross-cultural competence, influence, follower commitment, versatility and group organisation.

\section{Literature review and hypothesis development \\ Contextualising transformational leadership}

The term 'transformation' was first associated with Downton (1973), and was popularised by Burns (1978) through his research on leadership. Later, the concept of transformational leadership became the focus of research as an important leadership style in both business and non-business contexts (Bass \& Avolio, 1990; Bass, Waldman \& Avolio, 1978).

For most researchers and scholars, transformational leadership refers to a leadership style in which the leader and followers empower each other in terms of a higher level 
of morality and motivation (Burns, 1978). Bass (1985) observes that transformational leadership enables leaders to exceed their expected performance. This results in enhancement of followers' levels of trust, admiration and loyalty. It is a style that enables both the leader and followers to engage in mutually trusting commitment that generates above-normal results.

While some consider transformational leadership synonymous with transactional leadership, there are in fact significant differences between the two. Transactional leadership focuses on efficiency and making sure strategies are implemented at the middle and lower management levels, while transformational leadership focuses on effectiveness through creation of a harmonious working relationship between leaders and followers (Edward \& Gill, 2012). It has been argued that leaders need to develop transformational leadership behaviour and competencies to be effective and competitive (Amos, 2012). Others have asserted that both transactional and transformational leadership competencies are required to ensure leaders' effectiveness irrespective of the level in the organisation (Bass \& Avolio, 1995). Various studies have found that transactional and transformational leadership contribute to subordinate satisfaction, performance, inspiration and positive attitude among organisational membership (Avolio, Howell \& Sosik, 1999).

Despite support for both types of leadership competencies, transformational leadership is considered to be more critical. For instance, Walumbwa, Avolio and Zhu (2008) note that there are numerous research focusing on effective transformational leaders and their relationship with followers. Bass and Avolio (1995) contend that using transformational leadership is the ideal way to help deal with contemporary business world challenges. Similarly, Shadraconis (2013) argues that the transformational style is effective during times of crisis as it gives organisational leaders the platform to exercise their authority and respond accordingly. This suggests that transformational leadership is appropriate to addressing the Kenyan indigenous bank challenges and could be associated with the positive performance of the industry in the recent past.

\section{Conceptualising transformational leadership competence}

Transformational leadership is understood to positively affect the productivity of followers or employees, and of the overall effectiveness of the organisation (Tuuk, 2012), owing to the competencies associated with this leadership style. To measure transformational leadership, scholars and researchers have over the years developed different attributes, referred to in this study as transformational leadership sub-variables (Bass, 1990; Bass \& Avolio, 1994; Hall, Johnson, Wysocki \& Kepner, 2012; Hayward, 2005; Hebert, 2011). Bass and Avolio (1990, 1994) single out four main sub-variables associated with transformational leadership, namely, inspirational motivation, intellectual stimulation, individualised consideration and idealised influence attributes (commonly known as the Four I's).
However, a more recent study by Hayward (2005) identified an additional sub-competency of idealised influence behaviour, which is included in this study as the fifth subcompetency, making a contribution to the theoretical conceptualisation of transformational leadership. The five sub-variables are discussed below.

Inspirational motivation denotes a leader's ability to inspire and mentor others (Bass \& Avolio, 1994), a task achieved through good communication skills and mentoring, visioning, corrective action and risk-taking. Furthermore, the leader is a hard worker with confidence that inspires optimism among employees, especially during crises (Hebert, 2011). These leaders also encourage individual championship and team spirit in order to attain set goals and realise high performance in terms of revenues and growth (Hall et al., 2012).

Intellectual stimulation emphasises a leader's ability to be creative and innovative (Bass \& Avolio, 1994; Hall et al., 2012) in encouraging their followers to be creative by providing a conducive environment to test and develop new ideas (Bass, 1990). In a business context, this enables employees to courageously think independently of ways to improve their performance and creative ability, thereby providing solutions to critical organisational problems and challenges (Bass, 1990; Hebert, 2011).

In terms of individual consideration, the leader is said to have the ability to assess, diagnose and evaluate employees' individual needs rather than treating them as a group (Bass \& Avolio, 1994). This approach ensures that the needs of individuals are identified, addressed and mentorship provided to equip employees with skills to deal with challenging opportunities or positions (Bass, 1990; Hall et al., 2012).

Idealised influence competencies relate to a leader's ability to capture and communicate a vision and mission, successfully showing respect, building confidence and trust among followers or employees while at the same time encouraging them to pursue individual or collective goals (Bass, 1995). The leader also exhibits role model behaviour and is inspirational, considerate and able to stimulate self and others in terms of creativity and innovativeness (Hall et al., 2012; Hebert, 2011).

Idealised influence behaviour focuses on the leader's ability not only to have a vision and mission for the organisation and its members but also to demonstrate the appropriate behaviour desired for effective performance (Hayward, 2005).

\section{Conceptualising leadership effectiveness}

The term 'effectiveness' refers to the ability to realise set goals or objectives (Yukl, 2010). In relation to leadership, effectiveness denotes a leader's ability to steer an organisation towards attaining set goals (Green, 2010; Yukl, 2010). Though essential to organisational performance, defining leadership effectiveness remains controversial with little agreement on 
the common definition both in the past and among contemporary scholars and researchers (Arnold, Cooper \& Robertson, 1998). In this regard, Stogdill (1974), Bass (1981) and Bass (1990) catalogued and interpreted about 5000 studies where they found great differences in definition. Emphasising these differences, Burns (1978) notes that leadership effectiveness 'is one of the most observed and least understood phenomena on earth'. For example, Norma (1997) and Yukl (1994) defined leadership effectiveness as a process whereby one person influenced other people's behaviour with an aim to achieve set goals. Such a leader must also win the followers' attention and commitment in order to realise set goals. For most scholars, however, leadership effectiveness is demonstrating appropriate skills, abilities, beliefs and behaviour (Green, 2010; Yukl, 2010) to achieve a desired goal. For this study, leadership effectiveness implies the leader's ability to exercise personal influence, skills and abilities to accomplish expected goals or objectives (Cooper et al., 2012).

To measure leadership effectiveness, scholars and researchers have developed many different attributes, referred to in this study as leadership effectiveness sub-variables (Epitropaki \& Martin, 2005; Green, 2010). Some of these attributes include ability to inspire a shared vision, foster unity, exercise power effectively, empower others, establish appropriate learning environment, satisfy job-related needs of employees, group organisation, follower satisfaction, follower commitment, level of impact, cross-cultural competence and versatility (Green, 2010; National Centre for Research in Vocation Education, 1994; Yukl, 2010). Further research identified five sub-variables as most appropriate measures of leadership effectiveness, namely, cross-cultural competence, influence, follower commitment, versatility and group organisation (Green, 2010). The current study used the latter five subvariables to measure leadership effectiveness in the indigenous banking industry. The five sub-variables are discussed below.

Cross-cultural competence denotes the leader's ability to work with and attain results from followers coming from different cultures (Green, 2010). Several studies highlight the role of cross-cultural competence in shaping the leader's behaviour and the increasing demand to have leaders who are able to manage diversity in the workplace (Earley \& Ang, 2003; Johnson et al., 2006). For instance, Yukl (2010) emphasises the importance of recognising the role of cultural competency and diversity management as influencing the leader's behaviour. However, Johnson et al. (2006) recognise that there is insufficient research on cross-cultural competence particularly in international business arenas and therefore wanting its inclusion in this study.

Influence implies the leader's ability to impact on the behaviour of others to achieve the desired results (Green, 2010). To be effective, a leader's influence must make a positive impression, not only on those supervised directly but also on the whole organisation. In applying influence, leaders should show understanding and appreciation of followers in order to gain their commitment and attention.
Follower commitment refers to organisational members' commitment and dedication to a common goal and objective (Green, 2010). Follower commitment is a key determinant of a leader's effectiveness, and it enables attainment of set goals and objectives in unison (Yukl, 2010). A leader who emphasises and supports follower commitment, results in an enthusiastic workforce full of commitment and confidence in the leader and the leadership style, leading to positive and satisfactory performance.

Versatility indicates the leader's ability to work with others and obtain desired results. The concept is used in the context of obtaining results from others, especially different line managers and across departments (Green, 2010). Versatility is based on the increasing demand to have leaders manage people outside their traditional organisational structures or levels.

Group organisation refers to the way a group is organised to ensure it works effectively to achieve set goals (Yukl, 2010). Employees are greatly influenced by group organisation (Epitropaki \& Martin, 2005). According to prevailing literature, there is a need to have a positive leader-subordinate relationship, if effective work is to be realised, a goal which is achievable through group organisation. Similarly, the effectiveness of a leader is determined by understanding and being involved in group organisation. However, this can only be realised if the leaders and subordinates build strong mutual trust and respect, and work as a group (Epitropaki \& Martin, 2005). Yukl (2010) comments that subordinates must be satisfied with the leader if their group is to perform effectively. With increased emphasis on attaining leadership effectiveness in organisations, group organisation has become central to leadership success.

\section{Theoretical overview and hypotheses development}

As previously mentioned, transformational leadership is a style where both leaders and followers accept, consult and work together to achieve a common goal (Burns, 1978). According to the prevailing literature, transformational leadership results in understanding and change of attitude, beliefs and heart in order to realise set goals in a mutually acceptable and satisfying manner (Bass, 1985). Both literature and empirical evidence identify transformational leadership competencies mandatory for leaders to perform effectively, namely, inspirational motivation, intellectual stimulation, individualised consideration, idealised influence (attributes) and idealised influence (behaviours) as derived from Avolio and Bass (2004), Hall et al. (2012) and Hayward (2005). Several studies support transformational leadership competencies as key ingredients in ensuring leadership effectiveness (such as Avolio, Howell \& Sosik, 1999; Barling, Slater \& Kelloway, 2000; Edward \& Gill, 2012). To demonstrate the importance of transformational leadership competency in relation to leadership effectiveness, over 500 doctoral studies have been done since 1995 (Bass \& Avolio, 2004). From a majority of the studies, it is hypothesised that a strong relationship exists between transformational leadership competencies and leadership 
effectiveness (Avolio \& Bass, 2004; Edward \& Gill, 2012; Howell \& Hall-Marenda, 1999). Based on the theoretical review, the current study hypothesises an existence of a relationship between transformational leadership competency and leadership effectiveness within the indigenous banking sector in Kenya.

In order to achieve the purpose of this study, the hypothesised relationship between transformational leadership (independent variable) and leadership effectiveness (dependent variable) is depicted in Figure 1.

The following hypothesis is formulated and tested to establish the existence or lack of a correlation between transformational leadership and leadership effectiveness:

- Hypothesis $1\left(\mathbf{H}^{1}\right)$ : There is a positive correlation between transformational leadership and leadership effectiveness.

\section{Research design methodology}

This study used a positivist approach which is most suited to the quantitative nature of the data gathered to establish the relationship between transformational leadership competencies and leadership effectiveness.

\section{Sampling and response rate}

The population in this study consisted of 30 Kenyan indigenous banks and their employees. In order to participate in the study, respective market share was used to rank the banks ranging from the largest to the smallest. A sample of 15 (50\%) banks was selected based on the size of their market share, with 13 of them finally participating in the study. Non-probability sampling to purposely select managers or supervisors and simple random techniques to select non-managers were used, with a total of 494 participants. While 273 questionnaires were received back, only 257 were found to be usable for statistical analysis, a response of $55.3 \%$.

\section{Measuring instruments}

The self-administered measuring instrument consisted of a cover letter and four sections. Section 1 of the questionnaire had 20 statements containing information on Kenyan indigenous banking, bank existence, leadership competencies and growth. Section 2 on transformational leadership competency and Section 3 on leadership effectiveness had 25 statements, respectively. The measuring statements in

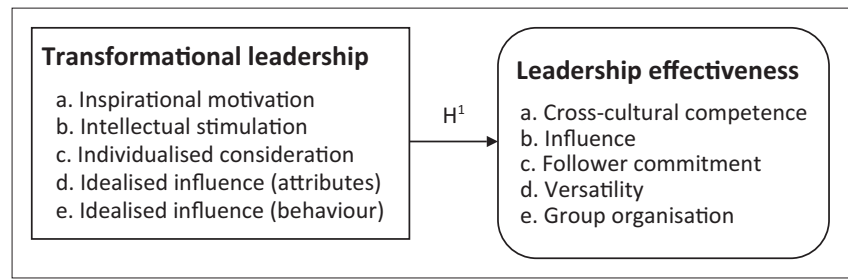

FIGURE 1: Proposed hypothesised framework of the relationship between transformational leadership and leadership effectiveness.
Sections 2 and 3 were made up of a multi-item labelled fivepoint Likert-type scale. As such, respondents indicated their level of agreement with given statements, where 1 = strongly disagree and $5=$ strongly agree. Section 4 focused on demographic information, ranging from sex, age, education level, work position to bank rating.

\section{Research procedure in data collection}

Prior to collecting the data, the researcher sought the permissions from the target banks for the study to be conducted. Furthermore a permit was attained from the National Council for Science and Technology (NCST), a government body responsible for research conducted in Kenya. In addition the study abided by the required research ethics standards requirements at Rhodes University. The questionnaire distributed was accompanied by a cover letter explaining the purpose of the research, importance of voluntary participation and confidentiality and the need for participants' consent before participation. Through the use of research assistants, some of the questionnaires were physically distributed and collected while others were administered and completed electronically as preferred by some respondents. The actual data collection took place over a period of 4 months.

\section{Data analysis}

To ensure the desired results were attained, structural equation modelling (SEM) was used for data analysis. Specifically, the software program AMOS (IBM SPSS Statistics, Version 21, 2013) was used for the SEM. The analysis included Cronbach's alpha (CA) and confirmatory factor analysis (CFA) to assess the discriminant reliability, validity of the measuring instrument and goodness-of-fit indices. From a SEM perspective, a response of 257 is sufficient for analysis. According to literature, an acceptable range for analysis is between 200 and 400 responses (Farrington, 2009). However, responses of between 150 and 200 have been used for analysis (Loehlin, 1992). There are other studies that have similarly argued that a sample of between 100 and 200 is appropriate (Hair, Anderson, Tatham $\&$ Black, 1998). This means that the response rate used for this study is within the accepted parameters.

\section{Results}

The descriptive statistics shows that the majority of the respondents from the current study are women (52.1\%) while men account for $47.9 \%$. The findings further indicate that most of the respondents $(63.8 \%)$ were aged between 25 and 40 years, placing most of the respondents as young employees. Similarly, over half of the respondents (54.4\%) were university graduates. A majority $(84 \%)$ worked in the banking industry for a period ranging from 1 to 10 years, of which $52.1 \%$ had worked at the bank for a period of between 1 and 5 years. Another finding indicates that more than half $(64.2 \%)$ of the respondents reported that their banks had experienced financial crisis. 


\section{Discriminant validity and reliability results}

In order to perform discriminant validity and reliability tests, both CFA and CA were conducted. First, CFA was conducted to establish the unique factors in the data and assess the discriminant validity of the scales measuring the independent and dependent variables. The validity of the transformational leadership competency, independent variable, termed a construct, was made up of five sub-constructs, namely, inspirational motivation, intellectual stimulation, individualised consideration, idealised influence (attributes) and idealised influence (behaviour). In this study, all factor analysis scores were acceptable at 0.3 (Hair, Black, Babin, Anderson \& Tatham, 2006). All the transformational leadership subconstructs were accepted after the measuring items loaded as expected and were therefore analysed further. The following CFA scores for the leadership competency sub-construct measuring scales were attained, namely, inspirational motivation (0.654), intellectual stimulation (0.545), individualised consideration (0.730), idealised influence attributes (0.700) and idealised influence behaviour (0.599). The five factors, previously referred to as sub-constructs, explain $69.3 \%$ of the variance in the data.

Similarly, the five sub-constructs of the dependent variable, leadership effectiveness (cross-cultural competence, influence, follower commitment, versatility and group organisation) were used in the CFA test. The result was that three of the subconstructs loaded successfully with CFA scores of influence (0.759), follower commitment (0.752) and versatility (0.738). Two factors (group organisation and cross-cultural competence) failed to load at the minimum factor analysis score of 0.3 . The three factors that loaded successfully explain $48.6 \%$ of the variance in the data.

The CA's assessment was done to establish the reliability of the scales of the measuring instrument. The independent variable (transformational leadership competency) and dependent variable (leadership effectiveness) constructs gave CA scores of 0.953 and 0.914 , respectively. The scores were considered very reliable compared to the minimum acceptable score of 0.7 (Nunnally, 1978). For all factors, coefficients of greater than 0.7 (Nunnally, 1978, p. 226) were returned. Sufficient evidence of validity and reliability for the scales measuring the independent and dependent variables is thus provided. The specific scores for transformational leadership sub-constructs were: individualised consideration (0.892), idealised influence behaviour (0.844), inspirational motivation (0.868) intellectual simulation (0.869) and idealised influence attributes (0.849). The CA scores are in agreement with similar studies, thereby making the measuring instrument and data reliable (Hayward, 2005).

Similarly, the result for the sub-constructs for leadership effectiveness that were retained for further analysis in this study had the following scores: influence (0.759), follower commitment (0.752) and versatility (0.738). The results indicated that the items used to measure leadership effectiveness construct were reliable with all the scores being greater than 0.7 . The findings also agree with similar studies (Green, 2010).

\section{The results of structural equation modelling}

The results of both the CFA and CA indicate that all of the sub-constructs (independent variable) were accepted for analysis. Two sub-constructs from the dependent variable (cross-cultural competencies and group organisation) failed to load as expected and were consequently dropped from further analysis. The changes in the number of sub-constructs required for further analysis led to the modification of the proposed theoretical framework, henceforth referred to as a model (see Figure 2).

To determine the goodness-of-fit for the model and to test the hypotheses, SEM was used. Similarly, in order to validate and test the hypotheses and sub-constructs, SEM was conducted for transformational leadership and leadership effectiveness constructs. Because of space constraints, the structural relationship models have not been included in this article. Instead, the structural and measurement model for transformational leadership and its sub-constructs is shown in Table 1.

\section{Goodness-of-fit}

A goodness-of-fit test is usually conducted in order to measure the fitness of the actual or observed input correlation or covariance in relation to the prediction made by a theoretical model (Hair et al., 1998). In this study, the goodness-of-fit was determined using four measures, namely, normed Chi-square (the ratio of Chi-square to degrees of freedom $\left[\chi^{2} / d f\right]$, the root mean square error of approximation [RMSEA], the goodness-of-fit index [GFI] and the comparative fit index [CFI]). The criteria used to measure goodness-of-fit indices are shown in Table 2.

Based on the criteria set in Table 2, the results of the goodnessof-fit indices for transformational leadership are represented in Table 3.

As shown in Table 3, the results show that the Normed Chisquare or CMID/DF value is 3.599 and falls between 2.0 and 5.0, indicating a good fit (Hooper et al., 2008; Tabachnick \& Fidel, 2007). The RMSEA value is 0.101 , which is above the maximum acceptance fit value of 0.08 and is therefore a poor fit and unacceptable (Grimm \& Yarnold, 2000). The GFI value of 0.813 is less than 0.90 . However, according to $\mathrm{Hu}$ and

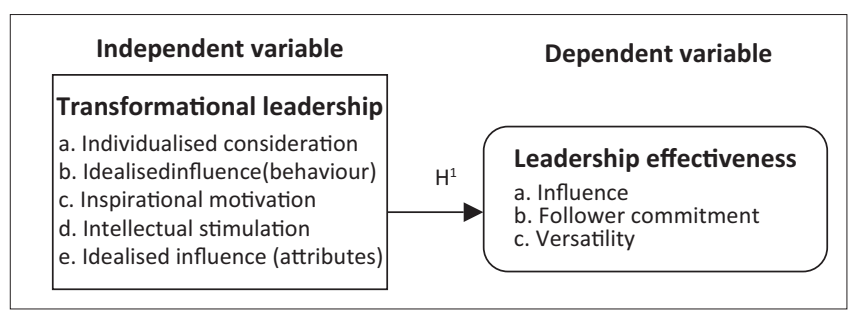

FIGURE 2: The revised hypothesised mode of the relationship between transformational leadership and leadership effectiveness. 
Bentler (1999), a value of 0.813 is still within acceptable fit. The final measure, CFI, has a value of 0.861 and is between 0.8 and 0.9, indicating a good fit (Byrne, 1998; Hooper et al., 2008). The CFI result value of 0.861 can therefore be termed as a good fit. With three of the tests (CMIN/DF, GFI and CFI) indicating good fits, there is a goodness-of-fit between the sub-model and approximation of the data.

In terms of the relationship between the transformational leadership competency construct and its sub-constructs, SEM analysis was used to establish if a relationship existed as shown in Table 4.

Table 4 demonstrates the existence of a positive correlation $(p<0.001)$ between all the sub-constructs and transformational leadership construct. The results indicated that all the transformational leadership sub-constructs are significant $(p<0.001)$ to transformational leadership competency.

The findings further showed that intellectual stimulation subconstruct (estimate $=0.663 ; p<0.001$ ) had greater influence on transformational leadership. This is followed by individualised consideration (estimate $=0.616 ; p<0.001$ ), idealised influence (attributes) (estimate $=0.570 ; p<0.001$ ), idealised influence (behaviour) (estimate $=0.488 ; p<0.001$ ) and inspirational motivation (estimate $=0.465 ; p<0.001$ ), respectively.

The relationship between the leadership effectiveness construct and its sub-constructs was also examined (see Table 5) rather than including the structural model of structural relationships in this article.

Based on the criteria indicated in Table 2, the results of the goodness-of-fit indices for leadership effectiveness are represented in Table 6.

The results of goodness-of-fit shown in Table 6 indicated a CMIN/DF value of 2.671, signifying a good fit between data and the sub-model. The RMSEA on the other hand had a value of 0.081 , indicating a poor goodness-of-fit (MacCullum et al., 1996). Similarly, the GFI value of 0.924 (Ghazali et al., 2013) and the CFI value of 0.921 indicate a very good fit (Hair et al., 2006). With three of the tests (CMIN/DF, GFI and CFI) indicating good fits, there is a goodness-of-fit between the sub-model and approximation of the data.

The relationship between the leadership effectiveness construct and its sub-constructs (influence, follower commitment and versatility) was analysed and confirmed by SEM. The findings showing the parameters and the p-values are presented in Table 7.

From Table 7, it is clear that there is a positive correlation $(p<0.001)$ between the leadership effectiveness construct and its sub-constructs. Based on importance, the influence subconstruct had the greatest impact (estimate $=0.717 ; p<0.001$ ), followed by follower commitment (estimate $=0.664 ; p<0.001)$ and finally versatility sub-construct (estimate $=0.483 ; p<0.001)$.

TABLE 1: Definition of structural constructs and measurements for the transformational leadership model and its sub-constructs.

\begin{tabular}{llll}
\hline Model & Construct & Sub-constructs & Measured or observed sub-constructs \\
\hline $\begin{array}{l}\text { Transformational leadership } \\
\text { structural model }\end{array}$ & $\begin{array}{l}\text { Transformational } \\
\text { leadership }\end{array}$ & $\begin{array}{l}\text { Idealised influence (attributes), Idealised influence (behaviour), Inspirational } \\
\text { motivation, Intellectual stimulation, Individualised consideration }\end{array}$ & - \\
$\begin{array}{l}\text { Transformational leadership } \\
\text { measurement model }\end{array}$ & - & Idealised influence (attributes) & Att1, Att2, Att3 \\
& - & Idealised influence (behaviour) & Beh1, Beh2, Beh3, Beh4 \\
& - & Inspirational motivation & Ins1, Ins2, Ins3, Ins4, Ins5 \\
& - & Intellectual stimulation & Sti1, Sti2, Sti3, Sti4 \\
\hline
\end{tabular}

TABLE 2: Criteria for goodness-of-fit indices.

\begin{tabular}{|c|c|c|}
\hline Goodness-of-fit measure & Types of test & Criteria \\
\hline $\begin{array}{l}\text { Normed Chi-square } \\
\left(\chi^{2} / \text { degree of freedom) }\right.\end{array}$ & Absolute fit and model parsimony & $\begin{array}{l}0.00 \text { to }<1.90 \text { indicates a very good fit (Politis, 2003; Ullman, 2001) } \\
2.00-5.00 \text { indicates a good fit } \\
5.0 \text { indicates acceptable fit } \\
>5.00 \text { indicates poor fit (Hooper, Coughlan \& Mullen, 2008) }\end{array}$ \\
\hline $\begin{array}{l}\text { The root mean square error of } \\
\text { approximation (RMSEA) }\end{array}$ & Absolute fit & $\begin{array}{l}0.00 \text { to }<0.05 \text { indicates a very good fit (Adendorff, 2004) } \\
0.051 \text { to }<0.060 \text { indicates a good fit (Grimm \& Yarnold, 2000; Hair et al., 1998; Hu \& Bentler, 1999) } \\
0.061-0.08 \text { indicates an acceptable or reasonable fit (Hu \& Bentler, 1999) } \\
>0.08 \text { indicates a poor fit (MacCullum, Browne \& Sugawara, 1996) }\end{array}$ \\
\hline The goodness-of-fit index (GFI) & Absolute fit & $\begin{array}{l}0.91-0.95 \text { is considered a very good fit (Ghazali, Ahmad, Uli, Suandi \& Hassan, 2013) } \\
0.90-0.84 \text { indicates good fit (Keskin, 2014) } \\
0.85 \text { to } \leq 0.89 \text { indicates acceptable fit (Keskin, 2014) } \\
0.0-0.84 \text {, with higher values indicating better model fit (Hu \& Bentler, 1999) }\end{array}$ \\
\hline Comparative fit index (CFI) & Incremental fit & $\begin{array}{l}0.90 \text { to } \leq 0.95 \text { indicates a very good fit (Hair et al., 2006) } \\
\text { Between } 0.50 \text { and } 0.89 \text { indicates good fit (Byrne, 1998; Hooper et al., 2008; Hu \& Bentler, 1999) } \\
\text { Between } 0.3 \text { and } 0.5 \text { is an acceptable fit (Fan, Thompson \& Wang, 1999) } \\
0 \geq \text { indicates poor fit (Li, 2007) }\end{array}$ \\
\hline
\end{tabular}

Source: Muriithi, S.M. (2015). Relationship between leadership and organisational effectiveness among indigenous banks in Kenya. Unpublished PhD thesis, Rhodes University, Grahamstown, South Africa

Note: Please see the full reference list of the article, Louw, L. Muriithi, S.M., \& Radloff, S. (2017). The relationship between transformational leadership and leadership effectiveness in Kenyan indigenous banks. SA Journal of Human Resource Management/SA Tydskrif vir Menslikehulpbronbestuur, 15(0), a935. https://doi.org/10.4102/sajhrm.v15i0.935, for more information. 
TABLE 3: Goodness-of-fit indices for the structural model transformational leadership.

\begin{tabular}{ll}
\hline Goodness-of-fit measure & Criteria \\
\hline Sample size & 257 \\
Normed Chi-square ( $\chi^{2} /$ degree of freedom) & 3.599 \\
The root mean square error of approximation (RMSEA) & 0.101 \\
Goodness-of-fit index (GFI) & 0.813 \\
Comparative fit index (CFI) & 0.861 \\
\hline
\end{tabular}

TABLE 4: Structural model parameter estimates and $p$-values for transformational leadership and its sub-constructs.

\begin{tabular}{lcccc}
\hline $\begin{array}{l}\text { Transformational } \\
\text { sub-constructs }\end{array}$ & Estimates & S.E & C.R & $P$ \\
\hline $\begin{array}{l}\text { Transfrm<--- Idealised } \\
\text { influence (attributes) }\end{array}$ & 0.570 & 0.055 & 10.416 & $* * *$ \\
$\begin{array}{l}\text { Transfrm<---- Idealised } \\
\text { influence (behaviour) }\end{array}$ & 0.488 & 0.046 & 10.628 & $* * *$ \\
$\begin{array}{l}\text { Transfrm<--- Inspirational } \\
\text { motivation }\end{array}$ & 0.465 & 0.046 & 10.003 & $* * *$ \\
$\begin{array}{l}\text { Transfrm<---- Intellectual } \\
\text { stimulation }\end{array}$ & 0.663 & 0.054 & 12.179 & $* * *$ \\
$\begin{array}{l}\text { Transfrm<---- Individualised } \\
\text { consideration }\end{array}$ & 0.616 & 0.057 & 11.858 & $* * *$ \\
\hline
\end{tabular}

TABLE 5: Definition of structural constructs and measurements for the leadership effectiveness model and its sub-constructs.

\begin{tabular}{|c|c|c|c|}
\hline Model & Construct & Sub-constructs & $\begin{array}{l}\text { Measured or observed } \\
\text { measuring items }\end{array}$ \\
\hline $\begin{array}{l}\text { Leadership } \\
\text { effectiveness } \\
\text { structural model }\end{array}$ & $\begin{array}{l}\text { Leadership } \\
\text { effectiveness }\end{array}$ & $\begin{array}{l}\text { Influence, follower } \\
\text { commitment, } \\
\text { versatility }\end{array}$ & - \\
\hline $\begin{array}{l}\text { Leadership } \\
\text { effectiveness } \\
\text { measurement } \\
\text { model }\end{array}$ & - & $\begin{array}{l}\text { Influence } \\
\text { Follower commitment } \\
\text { Versatility }\end{array}$ & $\begin{array}{l}\operatorname{Inf1}, \operatorname{Inf} 2, \operatorname{Inf} 3, \operatorname{Inf} 4, \operatorname{Inf5} \\
\text { Fol1, Fol2. Fol3 } \\
\text { Ver1, Ver2, Ver3, Ver5 }\end{array}$ \\
\hline
\end{tabular}

TABLE 6: Goodness-of-fit indices for the structural model leadership effectiveness.

\begin{tabular}{ll}
\hline Goodness-of-fit measure & Criteria \\
\hline Sample size & 257 \\
Normed Chi-square $\left(\chi^{2} /\right.$ degree of freedom) (CMIN/DF) & 2.671 \\
The root mean square error of approximation (RMSEA) & 0.081 \\
Goodness-of-fit index (GFI) & 0.924 \\
Comparative fit index (CFI) & 0.921 \\
\hline
\end{tabular}

The results demonstrated that influence, follower commitment and versatility were critical measures of leadership effectiveness.

\section{Transformational leadership and leadership effectiveness}

In terms of transformational leadership and leadership effectiveness, the goodness-of-fit indices showed a good fit between the proposed measurement and structural submodel, therefore representing acceptable approximation of the data (Table 8).

The results of goodness-of-fit shown in Table 8 illustrate a CMIN/DF value of 1.704, signifying a very good fit between data and the sub-model (Politis, 2003; Ullman, 2001). Similarly, the RMSEA value of 0.052 indicates a good fit (Grimm \& Yarnold, 2000; Hair et al., 1998; Hu \& Bentler, 1999). The GFI value of 0.982 is very good (Ghazali et al., 2013). Finally, the CFI value of 0.922 showed a very good fit (Hair et al., 2006). With four tests (CMIN/DF, RMSEA, GFI
TABLE 7: Structural model parameter estimates and $p$-values for leadership effectiveness and its sub-constructs.

\begin{tabular}{lcccc}
\hline $\begin{array}{l}\text { Leadership effectiveness } \\
\text { sub-constructs }\end{array}$ & Estimates & S.E & C.R & $\boldsymbol{P}$ \\
\hline Leadeff <---- Influence & 0.717 & 0.056 & 12.747 & $* * *$ \\
$\begin{array}{l}\text { Leadeff <---- Follower } \\
\text { commitment }\end{array}$ & 0.664 & 0.056 & 11.850 & $* * *$ \\
Leadeff <---- Versatility & 0.483 & 0.058 & 8.372 & $* * *$ \\
\hline
\end{tabular}

$* * *, p<0.001$

TABLE 8: Goodness-of-fit indices for transformational leadership and leadership effectiveness.

\begin{tabular}{ll}
\hline Goodness-of-fit measure & Criteria \\
\hline Sample size & 257 \\
Normed Chi-square $\left(\chi^{2} /\right.$ degree of freedom) (CMIN/DF) & 1.704 \\
The root mean square error of approximation (RMSEA) & 0.052 \\
Goodness-of-fit index (GFI) & 0.982 \\
Comparative fit index (CFI) & 0.922 \\
\hline
\end{tabular}

TABLE 9: Structural model parameter estimates and $p$-values for transformationa and leadership effectiveness.

\begin{tabular}{lcccc}
\hline $\begin{array}{l}\text { Tranformation-leadership } \\
\text { constructs }\end{array}$ & Estimates & S.E & C.R & $\boldsymbol{P}$ \\
\hline Tran_L<---- Lead_compet & 0.992 & 0.065 & 15.268 & $* * *$ \\
Inf <-----Lead_compet & 0.612 & 0.051 & 12.052 & $* * *$ \\
Fol <-----Lead_compet & 1.000 & - & - & - \\
Ver <----Lead_compet & 0.660 & 0.660 & 9.963 & $* * *$ \\
\hline
\end{tabular}

***, $p<0.001$

and CFI) being successful, this indicates a goodness-of-fit between the sub-model and approximation of the data.

The relationship between transformational leadership and leadership effectiveness constructs was examined as shown in hypothesis $\mathrm{H}^{1}$ :

- Hypothesis $\mathbf{1}\left(\mathbf{H}^{1}\right)$ : There is a positive correlation between transformational leadership and leadership effectiveness.

Following SEM analysis, the result indicated a strong positive correlation between transformational leadership and leadership effectiveness constructs. The analysis indicating the parameters and the $p$-values are shown in Table 9 .

Table 9 indicates a strong and positive correlation $(p<0.001)$ between transformational leadership construct (estimate $=1.000$; $p<0.001$ ) and leadership effectiveness construct. The findings support hypothesis $\mathrm{H}^{1}$ and are in agreement with similar studies that advocate the presence of a strong correlation between transformational leadership and leadership effectiveness (Amos, 2012; Avolio \& Bass, 2004; Hayward, 2005; Samson \& Daft, 2012).

\section{Discussion \\ Outline of results}

The study has found that the transformational leadership sub-constructs are an important ingredient for leadership effectiveness within the Kenyan indigenous banking industry. The specific transformational leadership subconstructs were found to be relevant and in order of ranking were intellectual stimulation, individualised consideration, idealised influence (attributes), idealised influence 
(behaviour) and inspirational motivation. From the results, it can be concluded that there existed a positive correlation between all transformational sub-constructs and transformational leadership competency. This means that effective transformational leaders are able to intellectually stimulate and motivate their followers. The leaders are also able to give individualised consideration to those under their care. Such leaders are also able to apply idealised influence (attributes and behaviour) while at the same time inspiring themselves and their followers. The results of the study are in agreement with similar studies where all the five sub-constructs were found to be significant to transformational leadership competency (Avolio \& Bass, 2004; Hayward, 2005). The results are significant to the banking leadership and show the need for the leadership to develop their transformational leadership competencies in order to be effective in their performance. The findings are in agreement with similar studies that have demonstrated a strong positive relationship between transformational leadership and leadership effectiveness (Donnelly, 1994; Kubicek, 2011; Northouse, 2013; Weese, 1994; Yukl, 2010). Similarly, the leadership effectiveness construct was found to have three main attributes of effectiveness within indigenous banking in Kenya, namely follower commitment, versatility and influence. From the findings, follower commitment was the most important attributes of leadership effectiveness followed by versatility and then by leader influence. Based on the findings, the bank leadership should ensure that the right transformational leadership competencies are sought from all bank employees in order to ensure effectiveness. With leadership effectiveness, the bank leaders should now be more aware of which attributes are most influential in enhancing the banks' sustainability.

\section{Practical implications}

The current study on the relationship between transformational leadership and leadership effectiveness has implications for both theory and practice and organisational leadership in general. First, the study has confirmed the existence of a relationship between transformational leadership and leadership effectiveness in the indigenous banking industry in Kenya. Second, the study has added valuable knowledge to the field of transformational leadership and leadership effectiveness in relation to the banking industry in Kenya. The findings therefore indicate that bank leadership cannot ignore transformational leadership competencies as essential to their success if they have to be effective in their leadership endeavours.

\section{Limitations and recommendations}

The study concentration on transformational leadership competency is a limitation because there are other competencies that may affect or influence leadership effectiveness. The study therefore recommends that more studies be conducted on other leadership competencies. This will bring more understanding on the determinants of leadership effectiveness within the banking industry and in other organisations.

\section{Conclusion}

The current study found a significant relationship between transformational leadership competencies and leadership effectiveness among the leaders in the Kenyan indigenous banking industry. The study identified required transformational leadership competencies and leadership effectiveness attributes relevant to the Kenyan indigenous banking industry. The findings therefore answered the key questions of this research by indicating that transformational leadership competencies of the leadership in the Kenyan indigenous banks are positively correlated to the leadership effectiveness and could be attributed with the current positive performance of the sector. This study therefore emphasised the need to have banks identify the appropriate competencies for their leaders and employees. It is also necessary to match the appropriate leadership competencies with leadership effectiveness attributes of effectiveness.

\section{Acknowledgements Competing interests}

The authors declare that they have no financial or personal relationships that may have inappropriately influenced them in writing this article.

\section{Authors' contributions}

S.M.M. was the principal investigator responsible for the fieldwork and the co-writing of this article. L.L. was the academic supervisor and was responsible for the overall leadership and designing of the study and co-writing, editing, finalisation and submission of this article. S.R. was responsible for the statistical analysis of data, presentation and interpretation using relevant tools and research instrument(s). The writing of the article was a team effort.

\section{References}

Adendorff, C.M. (2004). The development of a cultural family business model of good governance for Greek family businesses in South Africa. Unpublished doctoral thesis, Rhodes University, Grahamstown.

Al-Zoubi, B.R. (2012). Leadership competencies and competitive advantage: Empirical study on Jordan telecommunications. European Journal of Business and Management, 4(7), 234-247.

Ambutsi, P.B. (2005). A survey of corporate governance practices in selected commercial banks in Kenya. Unpublished MBA thesis, Daystar University, Nairobi.

Amos, T. (2012). Strategic leadership. In L. Louw \& P. Venter (Eds.), Strategic management: Developing sustainability in Southern Africa (2nd edn., pp. 439-476). Cape Town: Oxford University Press.

Arnold, J., Cooper, C., \& Robertson, I. (1998). Work psychology. Understanding human behaviour in the workplace. (3rd edn.). Harlow, England: Pearson Education.

Avolio, B.J., \& Bass, B.M. (2004). Multifactor leadership questionnaire: Third edition manual and sampler set. Redwood City, CA: Mind Garden.

Avolio, B.J., Howell, J.M., \& Sosik, J.J. (1999). A funny thing happened on the way to the bottom line: Humour as a moderator of leadership style effects. Academy of Management Journal, 42, 219-227. https://doi.org/10.2307/257094

Barling, J., Slater, F. \& Kelloway, E.K. (2000). Transformational leadership and emotional intelligence: An exploratory study. Leadership and Organizationa Development Journal, 21, 157-161. https://doi.org/10.1108/01437730010325040 
Barnes, R. (2013). Do you know your CEO? The eight essential leadership skills Retrieved March 06, 2013, from http://www.marketingmagazine.co.uk/ article/1174126/know-ceo-eight-essential-leadership-skills

Bass, B. (1990). Bass \& Stogdill's handbook of leadership: theory research and managerial applications. (3rd edn.). New York: Free Press.

Bass, B.M. (1981). Stogdill's handbook of leadership. New York: Free Press.

Bass, B.M. (1985). Leadership and performance. New York: Free Press.

Bass, B.M. (1995). Theory of transformational leadership redux. Leadership Quarterly, 6(4), 463-478. https://doi.org/10.1016/1048-9843(95)90021-7

Bass, B.M., \& Avolio, B.J. (1990). Developing transformational leadership: 1992 and beyond. Journal of European Industrial Training, 14(5), 21-37. https://doi. org/10.1108/03090599010135122

Bass, B.M., \& Avolio, B.J. (1994). Improving organizational effectiveness through transformational leadership. Thousand Oaks, CA: Sage.

Bass, B.M., \& Avolio, B.J. (1995). Multifactor leadership questionnaire (C). Randburg Productivity Development (Pty) Ltd.

Bass, B.M., Waldman, D., \& Avolio, B.J. (1978). Transformational leadership and the falling dominoes effect. Group and Organization Studies, 12(1), 73-86. https:// doi.org/10.1177/105960118701200106

Brunnermerier, M.K. (2009). Deciphering the liquidity and credit crunch 2007-2008. Journal of Economic Perspectives, 23(1), 77-100. https://doi.org/10.1257/ jep.23.1.77

Burns, J.M. (1978). Leadership. New York: Harper Row.

Byrne, B.M. (1998). Structural equation modeling with LISREL, PRELIS and SIMPLIS: Basic concepts, applications and programming. Mahwah, NJ: Lawrence Erlbaum Associates.

Cooper, J., Fenimore, J., \& Nirenberg, J. (Eds.). (2012). Leadership effectiveness. Encyclopaedia of leadership. Thousand Oaks, CA: Sage. Retrieved February 11 2011, from http://www.sagepub.com/northouse6e/study/materials/reference/ reference6.4.pdf

Donnelly, J.H. (1994). Reframing the mind of the banker: The changing skill set and skills mix for effective leadership. International Journal of Bank Marketing, 12(8), 12-16. Retrieved February 08, 2010, from http://www. Emeraldinsight.Com/insight/viewpdf. jsp?contenttype=article\&filename=html/output/published/emeraldfulltextarticle/ pdf/0320120802.pdf

Downton, J.V. (1973). Rebel leadership: Commitment and charisma in a revolutionary process. New York: The Free Press.

Earley, P.C. \& Ang, S. (2003). Cultural intelligence. Individual interactions across cultures. Stanford, CA: Stanford University Press.

Edward, G., \& Gill, R. (2012). Transformational leadership across hierarchical levels in UK manufacturing organisations. Leadership \& Organisational Development Journal, 33(1), 25-50. https://doi.org/10.1108/01437731211193106

Epitropaki, O., \& Martin, R. (2005). From ideal to real: A longitudinal study of the role of implicit leadership theories on leader-member exchanges and employe outcomes. Journal of Applied Psychology, 90(4), 659-676. https://doi. org/10.1037/0021-9010.90.4.659

Fan, X., Thompson, B. \& Wang, L. (1999). Effects of sample size, estimation methods, and model specification on structural equation modeling fix indixes. Structura Equation Modeling, 6(1), 56-83. https://doi.org/10.1080/10705519909540119

Farrington, S.M. (2009). Sibling partnerships in South African small and medium-sized family businesses. Unpublished MBA thesis, Nelson Mandela Metropolitan University, Port Elizabeth, South Africa.

Ghazali, R., Ahmad, A., Uli, J. Suandi, T., \& Hassan, S.A. (2013). Manager commitment to change: Commitment to change among managers in a selected service organization in Malaysia. In J.H. Westover (Ed.), Leadership and organisationa change (pp. 300-316). Champaign, IL: Common Ground Publication LLC.

Grant Thornton. (2013). 2013 banking outlook: Surviving and thriving in the new normal world of banking regulations. Chicago, IL: Grant Thornton Ltd.

Green, J.M. (2010). Factors affecting perceptions of leadership effectiveness in an international organization: A study of middle management in Finnish MNC. Unpublished PhD dissertation, Aston University, Birmingham, United Kingdom.

Grimm, L.G., \& Yarnold, P.R. (2000). Reading and understanding multivariate statistics. Washington, DC: American Psychological Association.

Hair, J.F., Anderson, R.E., Tatham, R.L., \& Black, W.C. (1998). Multivariate data analysis. (5th edn.). Englewood Cliffs, NJ: Prentice hall.

Hair, J.F., Black, W.C., Babin, B.J., Anderson, R.E., \& Tatham, R.L. (2006). Multivariate data analysis. (6th edn.). Upper Saddle River, NJ: Pearson Prentice Hall.

Hall, J., Johnson, S., Wysocki, A., \& Kepner, K. (2012). Transformational leadership: The transformational of managers and associates. Gainesville, FL: University of Florida Institute of Food and Agricultural Sciences. Retrieved November 04, 2012, from http://edis.ifas/ufl.edu/DLN

Hayward, B.A. (2005). Relationship between employee performance, leadership and emotional intelligence in a South African parastatal organisation. Unpublished
master's thesis, Rhodes University, Grahamstown, South Africa.

Hebert, E.B., (2011). The relationship between emotional intelligence, transformationa leadership, effectiveness in school principals. Unpublished doctoral thesis, Georgia State University, Atlanta, GA.

Hedley, K., White, J., Roche, P.D.D.L., \& Banerjea, S. (2006). Banking 2015: A classic strategy battle of scale vs focus. Strategy \& Leadership, 34(3), 51-58. https://doi. org/10.1108/10878570610700875
Hogan, R., \& Warrenfeltz, R. (2003). Educating the modern manager. Academy of Management Learning and Education, 2(1), 74-84. https://doi.org/10.5465/ AMLE.2003.9324043

Hooper, D., Coughlan, J., \& Mullen, M.R. (2008). Structural equation modeling: Guidelines for determining model fit. The Electronic Journal of Business Research Methods, 6, 53-60. Retrieved August 30, 2010, from http://www.ejbrm.com

Howell, J. \& Hall-Marenda, K. (1999). The ties that bind: The impact of leader-member exchange, transformational and transactional leadership, and distance on predicting follower performance. Journal of Applied Psychology, 84(5), 680-694. https://doi.org/10.1037/0021-9010.84.5.680

Hu, L.-T., \& Bentler, P.M. (1999). Cut-off criteria for fit indexes in covariance structure analysis: Conventional criteria versus new alternatives. Structural Equation Modeling, 6(1), 1-55. https://doi.org/10.1080/10705519909540118

IBM Corporation. (2013). IBM SPSS Statistics for windows, version 21.0. Armonk, NY: IBM Corp.

Johnson, J., Lenartowicz, T., \& Apud, S. (2006). Cross-cultural competence in international business: Toward a Definition and Model. Journal of International Business Studies, 37, 525-543. https://doi.org/10.1057/palgrave.jibs.8400205

Keskin, H.K. (2014). A path analysis of metacognitive strategies in reading, Self-efficacy and task value. International Journal of Social Science \& Education, 4 (4), 798-808.

Kubicek, J. (2011). Leadership is dead: How influence is reviving it. New York: Howard Books.

$\mathrm{Li}, \mathrm{m}$. (2007). modeling the travel motivation of mainland Chinese outbound tourists. Purdue University Graduate School. Ann Arbor, MI: ProQest Information and Learning Company.

Loehlin, J. C. (1992). Latent variable models: An introduction to factor, path and structural analysis. (2nd edn.). Hillsdale: Lawrence Erlbaum.

Maccullum, R.C., Browne, M.W. \& Sugawara, H.M. (1996). Power analysis and determination of sample size for covariance structure modelling. In E. Vente (ed.), The succession process of small and medium-sized family businesses in South Africa. Unpublished doctoral thesis, Nelson Mandela Metropolitan University, Port Elizabeth.

Mlachila, M., Park, S.G., \& Yaraba, M. (2013). Banking in sub-Sahara Africa: The macroeconomic context. Washington, DC: International Monetary Fund, Publication Services.

Muriithi, S.M. (2015). Relationship between leadership and organisationa effectiveness among indigenous banks in Kenya. Unpublished PhD thesis, Rhodes University, Grahamstown, South Africa.

Mwangi, J. (2012). investors briefing. Nairobi: Equity Bank.

Nagar, N., Masih, E., \& Badugu, D. (2011). Retail banking: The new buzzword of today's world of banking. Journal of Banking Financial Services and Insurance Research, 1(8), 1-10.

National Centre for Research in Vocation Education (NCRVE). (1994). Leadership effectiveness index manual. Macomb, IL: National Center for Research in Vocational Education.

Njuguna, N. (2013). The importance of the banking sector in the Kenyan economy. Nairobi: Speech at the Bank of India, Kenya Branch, Diamond Jubilee Celebrations.

Norma, G.S. (1997). The role of leadership in business process reengineering: An empirical study of the relationship between leadership behaviour and the reengineering outcome. Los Angeles, CA: University of California.

Northouse, P.G. (2013). Leadership: Theory and practice. (6th edn.). Thousand Oaks, CA: SAGE.

Nunnally, J.C. (1978). Psychometric theory. (2nd ed.). New York: McGraw-Hill.

Pagon, M., Banutai, E. \& Bizjak, U. (2008). Leadership competencies for successful change management. University of Maribor. Retrieved April 10, 2013, from http://www.academia.edu/437506/Leadership_Competencies_for_Successful_ Change_Management

Politis, J.D. 2003. The connection between trust and knowledge management: What are its implications for team performance. Journal of Knowledge Management 7(5), 55-66. https://doi.org/10.1108/13673270310505386

Pricewaterhousecoopers (PWC). (2007). Initial perspectives on strategic and emerging banking issues in key African markets. Sunninghill: Pricewaterhousecoopers Inc.

Pricewaterhousecoopers (PWC). (2011). Financial focus 2011. Retrieved March 15, 2012, from www.pwc.com/ke/FinancialFocus-Jan2011

Samson, D., \& Daft, R.L. (2012). Management: Asia pacific edition. South Melbourne, Victoria: Cengage Learning Australia.

Shadraconis, S. (2013). Organisational leadership in times of uncertainty: Is transformational leadership the answer? LUX: A Journal of Transdisciplinary Writing and Research from Clemont Graduate University, 2(1), 28.

Sokpor, C.K.D. (2006). The role of CBK in controlling bank failures: an investigative study. Unpublished MBA thesis, Daystar University, Faculty of Post Graduate Studies, Nairobi, Kenya.

Stogdill, R.M. (1974). Handbook of leadership. New York: Free Express.

Tabachnick, B.G., \& Fidell, L.S. (2007). Using multivariate statistics. (3rd edn.). New York: HarperCollins College Publishers.

Tang, H.V., Yin, M., \& Nelson, D.B. (2010). The relationship between emotional intelligence and leadership practices: A cross-cultural study of academic leaders in Taiwan and the USA. Journal of Managerial Psychology, 25(8), 899-926. https:// doi.org/10.1108/02683941011089143 
Tuuk, E. (2012). Transformational leadership in the coming decade: A response to three major workplace trends. Cornell HR Review. Retrieved November 15, 2011 from http://digitalcommons.ilr.cornell.edu/chrr/25

Ullman, J.B. (2001). Structural equation modeling. In B.G. Tabachnick \& L.S. Fidell (Eds.), Using Multivariate Statistics (4th edn.) (pp. 653-771). Needham Heights, MA: Allyn \& Bacon.

Walumbwa, F.O., Avolio, B.J., \& Zhu, W. (2008). How transformational leadership weaves its influence on individual job performance: The role of identification and efficacy beliefs. Personnel Psychology, 61, 793-825. https://doi.org/10.1111/ j.1744-6570.2008.00131.x
Waweru, N.M., \& Kalani, M.V. (2009). Commercial banking crises in Kenya: Causes and remedies. African Journal of Accounting, Economics, Finance and Banking Research, 4, 12-32.

Weese, W.J. (1994). A leadership discussion with Dr. Bernard Bass. Journal of Sport Management, 8(3), 176-189.

Yukl, G. (2010). Leadership in organizations. (7th edn.). Upper Saddle River, NJ: Pearson Education Inc.

Yukl, G.A. (1994). Leadership in organizations. (3rd edn.). Englewood Cliffs: PrenticeHall. 